\title{
Chilean Graders' Behaviors and Perceptions of a Foreign Language Reschooling Program Towards Verbal Feedback on Pronunciation
}

\author{
Comportamiento y percepciones de estudiantado chileno de un programa de \\ reescolarización hacia la retroalimentación oral en la pronunciación en inglés
}

\section{Comportamento e percepções de estudantes chilenos a partir de um programa de reeducação visando a retroalimentação oral na pronúncia do inglês}

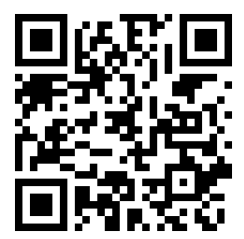

\author{
Sebastián Calisto-Miranda \\ Universidad de Concepción \\ Concepción, Chile \\ scalistom@gmail.com \\ iD https://orcid.org/0000-0001-7109-7733 \\ Mabel Ortiz-Navarrete \\ Universidad Católica de la Santísima Concepción \\ Concepción, Chile \\ mortiz@ucsc.cl \\ https://orcid.org/0000-0001-7481-1293
}

Recibido $\cdot$ Received $\cdot$ Recebido: $01 / 11 / 2017$
Corregido $\cdot$ Revised $\cdot$ Revisado: $10 / 12 / 2018$
Aceptado $\cdot$ Accepted $\cdot$ Aprovado: 02/ $05 / 2019$

\begin{abstract}
This research study aims to provide graders of an EFL reschooling program with individual verbal feedback and analyze their behaviors and perceptions towards the intervention. This study follows an action research design conducted during three sessions in which 28 secondary school students had a dialogue with the teacher who commented on their pronunciation issues and provided with strategies in order to help them deal successfully with pronunciation issues. A field note and a semi-structured interview were used to collect data. The field note was used during the dialogue to observe students' behavior towards the feedback; the semi-structured interview was implemented after the intervention in order to describe their perceptions towards the methodology and its effect on their learning process. Thematic analysis was used to identify certain patterns of meanings; the analysis showed findings leading to the conclusion that students felt more comfortable when facing speaking activities because of the practice and repetition during the individual verbal feedback stage. Future studies could include peer feedback, because this verbal feedback may be enhanced if students work in pairs. This type of strategy may favor discussion and clarification of doubts.
\end{abstract}

Keywords: Action research; individual feedback; verbal feedback; pronunciation; reschooling. 
doi: http://dx.doi.org/10.15359/ree.23-3.5

URL: http://www.una.ac.cr/educare

CORREO: educare@una.cr

Resumen: El principal objetivo de este estudio es proveer al estudiantado de un programa de reescolarización con retroalimentación oral individual, y analizar sus comportamientos y percepciones hacia la intervención. Se siguió un diseño de investigación-acción durante tres sesiones con 28 estudiantes de secundaria y su profesor, quien comentaba su pronunciación y entregaba algunas estrategias para ayudar a lidiar exitosamente con actividades orales. Se tomaron notas de campo y se aplicó una entrevista semiestructurada. Las notas durante el diálogo para observar y describir el comportamiento de estudiantes hacia la retroalimentación; y la entrevista, después de la intervención, para describir sus percepciones hacia la metodología y el efecto en su aprendizaje. El análisis temático fue utilizado para identificar patrones de significados y mostrar resultados que llevan a concluir que el grupo de estudiantes estaba más seguro al lidiar con actividades orales, debido a la práctica y repetición durante la etapa de retroalimentación oral individual. Futuros estudios pueden incluir retroalimentación en pares, debido a que la retroalimentación oral puede ser potenciada, si estudiantes trabajan en parejas. Este tipo de retroalimentación puede favorecer la discusión y la disipación de dudas.

Palabras claves:Investigación acción; pronunciación;retroalimentación individual;retroalimentación oral; reescolarización.

Resumo: O objetivo principal deste estudo é proporcionar ao grupo de estudantes de um programa de reeducação com retroalimentação oral individual, e analisar seus comportamentos e percepções em relação à intervenção. Foi feito um desenho de investigação-ação durante três sessões com 28 alunos do ensino secundário e o seu professor, que era quem comentava a sua pronúncia e fornecia algumas estratégias para os ajudar a lidar com sucesso as atividades orais. Foram tomadas notas de campo e aplicada uma entrevista semiestruturada. Foram tomadas anotações durante o diálogo para observar e descrever o comportamento dos alunos em relação a retroalimentação; e a entrevista, após a intervenção, para descrever as suas percepções em relação à metodologia e o efeito na sua aprendizagem. A análise temática foi utilizada para identificar padrões de significados e mostrar resultados que levam à conclusão de que o grupo de alunos estava mais confiante em lidar com atividades orais devido à prática e repetição durante a fase de retroalimentação oral individual. Estudos no futuro podem incluir retroalimentação em duplas, porque a retroalimentação oral pode ser melhorada se os estudantes trabalharem em pares. Este tipo de retroalimentação pode estimular a discussão e esclarecimento de dúvidas.

Palavras-chave: pesquisa de investigação-ação; retroalimentação individual; retroalimentação oral; pronúncia; reinserção escolar.

\section{Introduction}

English has always been difficult for Chilean students. The country is placed in the 42nd position according to EF EPI (Education First, 2016). In other words, despite all the efforts made by the Ministry of Education and schools, the country still has low levels of proficiency in the language. 
This study was conducted in a reschooling program which addresses students who have not finished their secondary education due to several reasons, mainly teenage pregnancy, illnesses, family issues, and unemployment. They attend school on a regular basis (Monday to Friday); however, as studies show (MINEDUC, 2016), despite the efforts of these programs to keep students studying and attending regularly, there is low internal efficiency: the attendance is irregular mainly due to life conditions, participants' job demands that results in drop-out rates close to $35 \%$ and failure rates $20 \%$.

In terms of the English language, one of the main problems regarding this reschooling program is the students' struggle with speaking activities as they are scared of making mistakes related to inappropriate pronunciation, forgetting simple or familiar words, or expressions. Besides, students feel it is not worth it to use English in their contexts; nevertheless, most of them acknowledge its importance and usefulness in the world. One of the most important challenges is the fact that education in these programs needs to be more individualized according to students' characteristics. Besides, teachers need to innovate using motivating methodologies so that students do not feel frustrated, and consequently, do not drop out (MINEDUC, 2016).

For this reason, as a way of encouraging students to participate in speaking activities and deal successfully with them, the research practitioner planned an intervention based on individual oral feedback on pronunciation. This strategy aims at having individual exchanges with students addressing their main pronunciation issues to deal successfully with speaking activities.

This article is funded by FONDECYT research project No. 11150273, entitled: Use of strategies for written corrective feedback in a wiki-based collaborative working environment: Impact and training plan.

\section{Theoretical Framework}

\section{Speaking language learning}

The speaking ability is the productive oral skill which "consists of producing systematic verbal utterances to convey meaning"(Bailey, 2003, p. 48). For the purpose of this study, speaking will be regarded as the ability to produce verbal utterances which carry meaning. Many problems related to the speaking skill are tied to external factors, such as lack of motivation and a friendly environment in the classroom. Willis (1996) states that "learners need chances to say what they think or feel and to experiment in a supportive atmosphere using language they have heard or seen without feeling threatened" (p. 7). That is why, when it comes to teach or suggest strategies to overcome speaking skill challenges, it is important to take different aspects into account. One aspect, students of an English as foreign language usually have problems with is pronunciation. 
doi: http://dx.doi.org/10.15359/ree.23-3.5

URL: http://www.una.ac.cr/educare

CORREO: educare@una.cr

\section{Speaking language learning issues: Pronunciation}

Pronunciation is a very essential aspect of communicative competence in a first or second language. In an EFL context students usually give a great deal of importance and they tend to not speak in English until they have a correct pronunciation. Chela-Flores (2001) suggests that pronunciation should be taught to beginners from the smallest unit (syllables), this means devoting early lessons to single words, phrases and sentences. In other words, it is essential for beginner students of English to start from basic elements. This will favor students' comfort and confidence when trying to produce words or sentences in English. However, apart from teaching effectively, teachers need to provide oral feedback on learners' pronunciation to guide their learning.

\section{Oral feedback}

Oral feedback offers several opportunities for students to be encouraged to learn. It is also a powerful force for moving pupils on and is the most regular and interactive form of feedback (DfES, 2004). Oral feedback in comparison to written feedback is more immediate due to the fact that it can be given at the moment students are performing a task, "with written feedback, students often have to wait longer to receive the feedback, and they might not have a chance to ask questions about the task or discuss with the teacher" (Pirhonen, 2016, p. 8). This means that oral feedback promotes more interaction between teachers and students. There are different types of oral feedback, as it is described below.

\section{Types of oral corrective feedback}

Lyster and Ranta (as cited in Tedick \& Gortari, 1998) present the following types of oral corrective feedback:

1. Explicit correction. Clearly indicating that the student's utterance was incorrect, the teacher provides the correct form....

2. Recast. Without directly indicating that the student's utterance was incorrect, the teacher implicitly reformulates the student's error, or provides the correction. ...

3. Clarification request. By using phrases like "Excuse me?" or "I don't understand," the teacher indicates that the message has not been understood or that the student's utterance contained some kind of mistake and that a repetition or a reformulation is required....

4. Metalinguistic clues. Without providing the correct form, the teacher poses questions or provides comments or information related to the formation of the student's utterance (for example,"Do we say it like that?"'That's not how you say it in French,"and"Is it feminine?").... 
5. Elicitation. The teacher directly elicits the correct form from the student by asking questions (e.g., "How do we say that in French?"), by pausing to allow the student to complete the teacher's utterance (e.g., "It's a....") or by asking students to reformulate the utterance (e.g., "Say that again."). Elicitation questions differ from questions that are defined as metalinguistic clues in that they require more than a yes/no response....

6. Repetition. The teacher repeats the student's error and adjusts intonation to draw student's attention to it. (pp. 2-3)

These are feedback strategies commonly used by teachers. Among them, recast, an implicit type of feedback, seems to be one of the most frequent strategy used by teachers in the classroom.

\section{Feedback challenges}

The importance of feedback is widely recognized; however, as it is time consuming many teachers avoid it. In reschooling programs, there are usually no less than thirty-three students and everyone comes with different levels of education. This make the provision of individual feedback a very challenging task, however, it is essential to individualize feedback with the objective of helping students to identify their errors. Another important challenge is how to address people, with different backgrounds and learning styles, into this process. It is said that "a personalized offer in education depends on really knowing the strengths and weaknesses of individual students through the use of data and dialogue to diagnose every student's learning needs" (OECD, 2006, p. 24). This means that teachers need to devote time to students, interact with them to identify their needs.

\section{Empirical studies on oral feedback}

There are different studies related to students' perceptions (understood in this study as the opinion students have about oral individual feedback on pronunciation) about oral feedback. In a study conducted by Alamri and Fawzi (2016), it was observed that students preferred recast and explicit correction. According to a study conducted in Iran by Ebrahimi and Hajmalek (2016) a change in the error correction strategy of speaking activities can potentially affect the negative attitude of the learners. One option preferred by students was to receive help from the teacher. A study carried out by Ölmezer-Öztürk (2016) about the types and timing of oral corrective feedback in EFL classrooms, students had different perceptions regarding the types and timing of oral corrective feedback provided by their teachers. Recasts and clarification requests was seen as ambiguous, and metalinguistic feedback as anxiety-provoking and difficult to understand. Besides, students did not feel comfortable when being corrected with immediate feedback, and its use was seen as discouraging by students in speaking activities in a classroom atmosphere. A research study carried out by Tolkhah (2008) about the effect of 
doi: http://dx.doi.org/10.15359/ree.23-3.5

URL: http://www.una.ac.cr/educare

CORREO: educare@una.cr

teachers' feedback on students' learning experiences during a speaking lesson, indicated that students expected their teacher to give them affective feedback. This expectation was viewed as a means to give the students the feeling of self-worth. It was also seen as reinforcement for students to stimulate their motivation to learn.

\section{Method}

The research design used to conduct the intervention is action research. This research design was chosen because this type of design has been described as a fairly common mode of investigation in educational research, especially among researchers interested in classroom teaching practices and teacher education Besides, it is described by Elliot (1991) as a social study used to improve the quality of action inside the classroom. The objective of this kind of research is to solve everyday and immediate problems, as well as to improve specific practices.

The action research model that was followed was proposed by Sandín (2003):

a) Detecting the problem of the research, clarify and diagnose it (it can be a social problem, a need for a change, an improvement, etc.).

b) Planning the action in order to solve the problem or introduce the change.

c) Implementing the plan and evaluate results.

d) Reflect to give a new diagnosis.

\section{Research question}

What are EFL reschooling program graders' behaviour and perceptions towards individual oral feedback on pronunciation?

\section{Participants}

This research was carried out in a reschooling program in Talcahuano. Students in this school come from different social backgrounds, yet the school is considered as a socially vulnerable school as it is located in an impoverished area of the city. In the group chosen to conduct the intervention, there were 28 students, 14 men and 14 women. The age range varied from 17 to 26 years old. All of them belonged to the same class. Despite their differences regarding social backgrounds and age, they all have in common the following: Failure in the regular schooling, behavioural issues, teen pregnancy and low school grades.

This sample was selected because not much research has been done in Chile with students who share the characteristics described above. Besides, this type of participant needs a lot of support and motivation due to the fact that their contact with English language is almost none and they usually do not see the effectiveness of learning English. 


\section{Intervention procedure}

The learning unit consisted of three lessons plus the evaluation, which was focused on:

a) Vocabulary (verbs, time, and frequency adverbs).

b) Pronunciation of these vocabulary items.

Each lesson consisted of three phases as Table 1 shows below:

Table 1: Lesson plan phases

Phase 1 An introduction in which there are speaking activities such as choral repetition.

Phase 2 A development stage in which students practice using the vocabulary doing speaking and listening activities, for instance, charades, miming games, bingo.

Phase 3 A closure in which students have a verbal interaction with the teacher. This stage is named as 'Individual oral feedback'.

Note: Own source.

In this exchange, the teacher provided students with feedback as pointed out by Sadler (2010). Specifically, during this intervention, the individual oral feedback went as follow:

a) The teacher reminded the student of the correct pronunciation.

b) The student said the word or sentence, and the teacher commented on his/her performance.

c) The teacher suggested some practice on a specific issue he thought the student should work on.

An example of the dialogue is shown below:

Teacher: Can you repeat this word, please?

Student: Ok.

Teacher: Listen (/'lisən/)

Student: /'listən/

Teacher: Remember, in the word 'Listen', you don't have to pronounce the letter ' $\mathrm{t}$ '. It is Listen (/'IISən/).

Student: Ok, the word is / 'IIsən/.

Teacher: That's right. 
doi: http://dx.doi.org/10.15359/ree.23-3.5

URL: http://www.una.ac.cr/educare

CORREO: educare@una.cr

\section{Instruments}

\section{Field notes}

This data collection technique was used in order to describe students' behaviour from what it is seen or heard (Ary, Jacobs, Sorensen, \& Razavieh 2010). This aligned with the audio recordings allows the research practitioner to write notes on any event that may be relevant to the study. This data collection technique was used in three sessions during the individual oral feedback phase in which students interacted with the teacher in order to receive comments and strategies related to their pronunciation. This was done in order to gather data related to their behaviour during the dialogue. This dialogue was also audio recorded in order to be accurate when reporting the data.

\section{Semi-structured interview}

The reason behind using this instrument is because it seeks for an understanding of a social phenomenon from the participant's own perspective and attempts to describe the findings as experienced by the subjects (Kvale \& Brinkmann, 2009). The semi-structured format was used in order to find out how students react and think about the individual oral feedback during and after the intervention while being exposed to the methodology. An interview guide was designed and so as to delimit certain themes and advanced queries. However, as other questions could emerge from the interview situation in itself during interaction, an audiorecording device was used with the participants' consent so as to accurately report the interview.

Each interview lasted 8 to 10 minutes. 8 students were interviewed and they were selected at random.

\section{Data analysis techniques}

For this purpose, the researcher used thematic analysis. This is a method for systematically identifying, organising, and offering insight into, patterns of meaning (themes) across a dataset (Braun \& Clarke, 2006). The researcher went through the following phases as suggested by Braun \& Clarke (2006):

Familiarization with the data: the researcher listened to the audio-recorded data transcribed it, read, and re-read it.

Coding: the researcher identified codes that are meaningful for the research question to guide the analysis.

Searching for themes: the researcher read the codes and found patterns in the data so that the collated data could be analyzed as themes. 
Reviewing themes: the researcher read the themes to check if these are coherent in relation to both the collated data and the full data-set.

Defining and naming themes: The researcher provided with names and definitions of each theme that summarize the main points of the codes.

Writing up: The researcher wrote an accurate and meticulous analysis that portrayed the most important aspects of the themes with empirical support.

In order to strengthen validity two procedures were used. First, codes and transcription were sent to another researcher in the field of study. Second, two instruments were used, the field notes and the semi-structured interview, in order to verify the results.

The Figure 1 illustrates the procedure used for the data analysis.

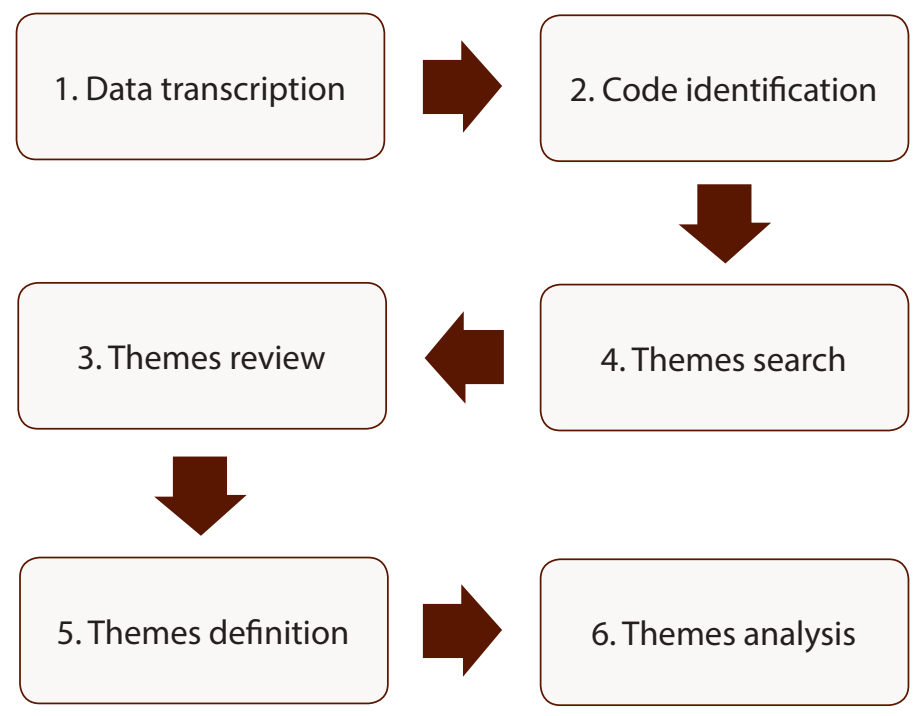

Figure 1: Data analysis. Note: Own elaboration.

\section{Results}

After having gone through the note fields and the semi-structured interview, the research practitioner read and analyzed the notes and listened carefully to the audio recordings to transcribe them and identify and organize patterns of meanings (themes across the data set). These patterns were labelled below to view essential events to determine the understanding of the participants' behaviours and perceptions. The following dimensions, themes and sub themes emerged from the analysis. To report the events not only as they were said, but also the manner in which they were said, the Jefferson system of transcription notation was used (Jefferson, 2004). These transcripts provide a detailed report of the interaction. 
doi: http://dx.doi.org/10.15359/ree.23-3.5

URL: http://www.una.ac.cr/educare

CORREO: educare@una.cr

\section{Dimension 1: Students' behaviour to individual oral feedback on pronunciation}

Table 2: Nervous laughter

\begin{tabular}{ccc}
\hline Theme & Frequency & \multicolumn{1}{c}{ Examples } \\
\hline Nervous laughter & 6 & $\begin{array}{l}\text { P1: "Wa(h)ke up" } \\
\text { P8: "Have weak.. wek.. heh" }\end{array}$ \\
\hline
\end{tabular}

Note: Own source.

According to Table 2, six participants reacted with nervous laughter when being exposed towards the repetition of words as they participated in the individual oral feedback phase.

Table 3: Unintelligible sounds

\begin{tabular}{clc}
\hline Theme & Frequency & Examples \\
\hline Unintelligible sounds & 4 & $\begin{array}{l}\text { P1: "Get dress- ( ) } \\
\text { P7: "Breakf- }(\text { )" }\end{array}$ \\
\hline
\end{tabular}

Note: Own source.

According to Table 3, four participants reported unintelligible sounds after listening to the modelled pronunciation of the word by the teacher. This was usually followed by a teacher's repetition so that the students could understand how the word was pronounced.

Table 4: Self-justification of their communication problems

\begin{tabular}{cll}
\hline Theme & Frequency & \multicolumn{1}{c}{ Examples } \\
\hline Self-justification of their communication problems & 7 & $\begin{array}{l}\text { P2: "Oiga, es que a mí me cuesta pronunciar" } \\
\text { P16: "Es que son muchas y me enredo" }\end{array}$ \\
\hline
\end{tabular}

Note: Own source.

According to Table 4, seven participants declared that some of the reasons behind their behaviour to the individual oral feedback were related to the inability to produce sounds, and, the amount of words being practiced each lesson.

Table 5: Students' self-correction

\begin{tabular}{|c|c|c|}
\hline Theme & Frequency & Examples \\
\hline Students' self-correction & 3 & $\begin{array}{l}\text { P5:"/estıdi/... / stıdi/!" } \\
\text { P8:"/ム ha:lf/... / ha:f/, aquí también va sin la 'L', ¿cierto?" }\end{array}$ \\
\hline
\end{tabular}

Note: Own source. 
According to Table 5, three students self-corrected when being interviewed at the individual oral feedback phase, producing the word with an extra sound, plus pauses, and followed by the correct word's pronunciation.

Table 6: Negative behaviour

\begin{tabular}{clc}
\hline Theme & Frequency & Example \\
\hline Negative behaviour & 7 & P14:"Profe, ando con flojera” \\
\hline
\end{tabular}

Note: Own source.

According to Table 6, participants had different attitudes or behaviours towards different activities done during individual oral feedback phase, seven learners declared that they were not willing to participate as they had gone through this the previous session, or, they were not in the mood of participating.

\section{Dimension 2:Students' perceptions towards individual oralfeedback on pronunciation}

This dimension is based on answers provided by participants who were asked what they thought about the oral feedback on pronunciation.

Table 7: Advantages of individual oral feedback over group feedback

\begin{tabular}{|c|c|c|}
\hline Theme & Frequency & Examples \\
\hline \multirow[t]{5}{*}{$\begin{array}{l}\text { Advantages of individual } \\
\text { oral feedback }\end{array}$} & 19 & $\begin{array}{l}\text { P1: "Si, me gusta que sea así desde practicar general a individual, los } \\
\text { primeros conceptos más general y después las palabras más específicas, } \\
\text { que tengan una pronunciación complicada...." }\end{array}$ \\
\hline & & $\begin{array}{l}\text { P6: "Si, así me gustaría que fuera, más individual, porque uno se siente } \\
\text { cómodo, así como que igual al exponerse, nos ponemos nerviosos". }\end{array}$ \\
\hline & & $\begin{array}{l}\text { P3: "Cuando es feedback grupal, uno cree que está haciéndolo bien pero, } \\
\text { pero resulta que no sabes cómo decir la palabra". }\end{array}$ \\
\hline & & $\begin{array}{l}\text { P4:"Cuando el feedback es grupal, no es igual, es que no a todos les cuesta } \\
\text { lo mismo... alguno no va a querer levantar la mano por vergüenza...". }\end{array}$ \\
\hline & & $\begin{array}{l}\text { P6: "La práctica individual me sirvió harto para estar más cómodo, así } \\
\text { puedo dar los trabajos con más naturalidad, lo puedo expresar mejor". }\end{array}$ \\
\hline
\end{tabular}

Note: Own source. 
doi: http://dx.doi.org/10.15359/ree.23-3.5

URL: http://www.una.ac.cr/educare

CORREO: educare@una.cr

According to Table 7, students gave their positive opinion regarding the individual oral feedback, they stated that it is better for them to practice as a group and, then, individually towards to improve on words they found difficult. Besides, students also mentioned they felt more comfortable and less anxious when receiving feedback individually. Likewise, they also expressed that when they are given group feedback they do not really know if what they are doing is correct. Besides, students all have different needs, this means group feedback cannot meet all those needs, especially in large classes.

In the following two charts, participants expressed what aspect of the individual oral feedback phase was relevant for their learning process.

Table 8: Relevant aspects regarding strategies during individual oral feedback phase

\begin{tabular}{lll}
\hline \multicolumn{1}{c}{ Theme } & Sub-theme Frequency & \multicolumn{1}{c}{ Examples } \\
\hline $\begin{array}{l}\text { Relevant aspects regarding } \\
\text { strategies during individual } \\
\text { oral feedback phase }\end{array}$ & Repetition 6 & $\begin{array}{l}\text { P5:“Si, la repetición, irla repitiendo para poderaprenderlas } \\
\text { porque uno es como materia pasada, materia olvidada, } \\
\text { entonces... es mejor ir repitiendo, hasta que nosotros..." } \\
\end{array}$ \\
& $\begin{array}{l}\text { P6: "Es que mientras más lo repitamos, más lo voy a } \\
\text { aprender... }\end{array}$ \\
\hline
\end{tabular}

Note: Own source.

According to Table 8, students stated that repetition was one of the most relevant aspects regarding the strategies conducted during the interview. They said that if they have regular pronunciation practice, they will be less likely to forget what they have just learned.

\section{Discussion}

The data detailed above highlighted some important findings as to how students' behaviours and perceptions regarding the individual oral feedback received affected their learning.

Before starting the intervention, I tried to think of a plan which could let students learn paying attention to their differences. This had always been an important issue, and, it still is; however, after conducting the intervention based on the individual oral feedback, there are some interesting facts regarding this group, that might be useful for other teachers who would like to read the insights into this process.

Firstly, the focus was on the behaviour that was observed during these sessions in which students and the teacher had the dialogue named individual oral feedback. This observation was essential to pay attention to specific issues related to how they deal with an activity like 
this. To begin with, they had never been provided with individual oral feedback, most of them were surprised at the fact of being individually called every lesson to know their progress and different strategies that could help them close the gap between what they did with what they were expected to achieve.

During the first session, participants started to utter nervous laughter and unintelligible sounds. These body responses displayed their predisposition towards speaking activities and especially towards pronunciation tasks. Making them repeat single words or expressions was unusual since prior speaking practice was done as a group. Besides, these responses were not noticeable since many students would refuse to talk in English and, consequently, hid these reactions so as not to show their nervousness or embarrassment when performing these tasks. This is a typical behaviour that students have when they face situations that are not really common in their routines such as speaking in English. In Chile, English is not in our immediate context, so students sometimes find the practice of English useless or unreal, especially when it comes to students who come from disadvantaged backgrounds. Besides, learners usually do not like to present in front of the class, and this behaviour is worsened when it is in English. Because of this, the lessons were designed to build students' self-confidence. As lessons went by, there were some improvements that could be observed, for example, fewer students reacted with these body responses, which might mean that as long as they were familiarized with activities, they were likely to feel more comfortable doing them. Nazarova and Umurova (2016) support this claim by suggesting that activities under the teacher's guidance are useful for encouraging self-confidence with beginners.

During the intervention, it was revealed that the sounds that are more difficult to pronounce by the students are initial and final sounds. Most of them were changed, deleted or some others were added so that they might be easily pronounced. Many students just repeated the words as they listened to them. However, after being told to compare the way they pronounced words and the correct pronunciation, and how they could improve, they started producing them better. For instance, students did not add 'e' at the beginning of the word 'study'. On other words, conducting one-to-one dialogues might be enhancing their individual performance. This means that more individual oral feedback was necessary. This is aligned with Hargreaves (2004), which supports the importance of feedback, the dialogue and the interaction between a teacher and a student to correct errors. This is an instance students really appreciate. However, it is important to say, that this individual oral feedback is a very challenging task due to the fact that as a teacher of a reschooling program, there are two issues that I usually face. The first one is related to students' attendance. Many students miss classes due to external factors, this means that not every student attends every lesson, and taking into account that they only have three hours of English each week, this instance only benefit those who have a regular attendance. The second one, refers to the frequency of feedback provision. Providing students with feedback every class or every time we encounter new vocabulary is an ambitious task, since most of the times, there are more than twenty-five students in the classroom. One alternative is to provide 
doi: http://dx.doi.org/10.15359/ree.23-3.5

URL: http://www.una.ac.cr/educare

CORREO: educare@una.cr

a more focused feedback. This means in this case to put an emphasis on those words whose mispronunciation may affect communication.

Another behaviour observed was students' self-justification of their communication problems. It is interesting that when it comes to participate in the individual oral feedback phase they declared some reasons behind their mispronunciations and how they affected their learning. For instance, some of them tended to state that they were not good at English and some others that they have always faced problems with pronunciation and recalling specific words. Reschooling graders as described before, usually have low self-esteem because they have gone through hard times in their lives. Some of them have failed in other schools or have not studied for a long time. Consequently, they are not accustomed to receiving feedback or strategies to improve. They think that whenever the teacher calls them it is to receive negative comments and that is why some of them refused to participate at first. They need more support than usual because they tend to become more frustrated when they are faced with activities that demand more work, so, working with them step by step (in this specific case, with word pronunciation) might be useful not only to develop their speaking skills but also to improve their self-esteem. Alexander (2001) declares that experience shows that change is slow: patterns of interaction are tied to culture and history. That is why, by bringing this strategy into the classroom might definitely improve students' willingness to participate. Over the sessions, students were more willing to participate and started recalling more words' pronunciation which shows the importance of these exchanges based on encouragement and feedback.

Self-correction was another behaviour observed. Some students started to develop reflective thinking skills since they self-corrected while they were practicing with their teachers. This selfawareness is very important for language learners, because without going through it, students might mislearn, as Steiner (2014) declares. Students do not usually have this high order thinking skills developed, that is why, as a teacher, I have to create more strategies to help those who need a push forward regarding their learning. Teachers are forced to reconfigure their roles in order to guide rather than control the processes of inquiry and knowledge production (Wolfe \& Alexander, 2008).

Even though, some students showed at first a negative behaviour toward the activity, it can be inferred that this behaviour has to do with their regular behaviour in the classroom, most of the participants showed a positive perception towards the individual oral feedback. Students who have failed in other schools usually do not come with a good predisposition to learn since they feel they will fail again. Some of them declared that not everyone has the same problems in English, in this sense, they see the importance of individual feedback. Besides, sometimes the noise that students make in the classroom is an important factor to consider. If everyone talks at the same time, maybe not everyone is doing it correctly, and consequently, there are some students who just utter words to show that they are practicing but are not doing it appropriately. That is why, working with individual oral feedback shows that teachers are worried about students' learning and encourage them to study and learn as they are not seen as a group but as individuals who are 
completely different and need different types of approaches. This claim is supported by Wolfe \& Alexander (2008) who stated that "by listening and responding to what children actually say and do, teachers are in a position to support individuals more effectively" (p. 8).

What students usually remembered the most from the intervention were two aspects; the first has to deal with final sounds. Individual practice played an important role here, modelling the pronunciation in front of each student made them pay attention to those issues who were relevant to them. Besides, it was interesting to notice that most of them were aware of their mother tongue pronunciation and how different it was from the one in English. Furthermore, having an objective for the following lesson was decisive. During the learning process, students not only need to be corrected, but they also need to be pushed towards a reachable objective which considers their own problems. Goal accomplishment can play a significant part in selfregulation (Sadler, 1989). Another important aspect students perceived as positive was repetition of words. It is important to highlight that students need practice in English, not only to learn specific contents, but also to deal with specific activities that are sometimes challenging and terrifying. Making students aware of how an evaluation will be, using similar practice during previous sessions to help language development, is essential to close the gap between failure and success. This is very important for beginners, a novice is, by definition:

unable to invoke the implicit criteria for making refined judgments about quality. Knowledge of the criteria is "caught" through experience. ... It is developed through an inductive process which involves prolonged engagement in evaluative activity shared with and under the tutelage of a person who is already something of a connoisseur. (Sadler, 1989, p. 135)

This means, scaffolding is an important part of the student's learning process. Repetition and constant practice might seem monotonous, but here is when teachers should vary their activities making them engaging and compelling in order to repeat contents but using different strategies.

\section{Conclusions}

This action research process helped me to see the importance of observing students' behaviour and working individually with them due to the fact that they can be more aware of their mistakes. The most noticeable drawback regarding this methodology is the teacher's capability to deal with every student to provide with individual oral feedback. In reschooling programs in Chile, the maximum quantity of students per classroom is thirty-three. Although not every student attends each lesson due to personal issues, the time assigned for each student during each lesson makes an absolute challenging task to appropriately deal with everyone. MINEDUC (2016) stated this claim as they regard this education as more individualized because of the students' needs. The OECD (2009) also claimed that smaller classes are often perceived as 
doi: http://dx.doi.org/10.15359/ree.23-3.5

URL: http://www.una.ac.cr/educare

CORREO: educare@una.cr

allowing teachers to focus more on the needs of individual students and reducing the amount of class time they spend dealing with disruptions. That is why, in order to conduct a similar intervention, the researcher should think of adapting her/his time according to the lesson schedule to save time and be able to diagnose each student's need.

Students valued the intervention in different ways. Most of them were asked how they felt after the methodology, and they showed their comfort towards the activities. My students expressed that they might have learned the pronunciation because of the exercises that made them repeat the words or expressions in different manners. In this sense, repetition and imitation play an important role when learning pronunciation and comprehension of oral English. This repetition that occurred during the individual oral feedback might have helped them because they were under the tutelage of an expert, this means a person who already knows what they need to accomplish. For learners with low self-esteem, and reschooling graders, of course, this is compulsory, once they know what they have to do, it is better for them to assume goals, and consequently, learn. Another important factor is that, through reflection, it can be noticed that every student needs different strategies and advice, taking into account that the context that they study demands more guidance. That is why, they became aware of this matter and considered the importance of receiving individual oral feedback.

This personalization is what matters in education and in reschooling programs. students appreciated the effort devoted by the teacher to provide with feedback addressing the particular needs detected in every student. This involvement on the part of the teacher makes them feel more confident and valued and this positively affects their attitude to the subject and to the skill under development. Teachers need to personalize education the best fashion they can to accomplish objectives not only suggested by governmental programs but also students' ones. This sense of ownership and knowledge of his or her own strengths and weaknesses will make students set achievable goals, and consequently, learn significantly.

As a conclusion and based on the outcomes of this study, some of the strategies that should be considered when treating and dealing with errors within a socially vulnerable context are: provision of individual feedback that facilitates interaction between the teacher and the student; the use of focused feedback to attend specific errors students make; the provision of frequent feedback and the use of scaffolding in order to assist students during the whole process to promote self correction.

Future works can include feedback among peers using the same methodology. We already know that this methodology worked and was useful for students who faced problems with speaking activities. Nonetheless, this guidance was provided by the teacher, so that is why, this progress does not stop here. As teacher's feedback can support students' performance, it would be advisable to promote peer feedback in the form of suggestions, doubts dissipation and ideas to each other in order to reinforce the feedback provided by the teacher in speaking activities. 


\section{References}

Alamri, B., \& Fawzi, H. H. (2016). Students' Preferences and Attitude toward Oral Error Correction Techniques at Yanbu University College, Saudi Arabia. English Language Teaching, 9(11), 59-66. doi: http://dx.doi.org/10.5539/elt.v9n11p59

Alexander, J. C. (2001) The Long and Winding Road: Civil Repair of Intimate Injustice. Sociological Theory, 19(3), 371-400. doi: https://doi.org/10.1111/0735-2751.00146

Ary, D., Jacobs. L. C., Sorensen, C. K., \& Razavieh, A. (2010). Introduction to research in education ( $8^{\text {th }}$ ed). California: Wadsworth.

Bailey, K. M. (2003). Speaking. In D. Nunan (Ed.), Practical English Language Teaching (pp. 47-66). McGraw-Hill. Retrieved from http://www.academia.edu/34135090/Practical English Language Teaching.pdf

Braun, V., \& Clarke, V. (2006). Using thematic analysis in psychology. Qualitative Research in Psychology, 3(2), 77-101. doi: http://dx.doi.org/10.1191/1478088706qp063

Chela-Flores, B. (2001). Pronunciation and Language Learning: An Integrative Approach. International Review of Applied Linguistics in Language Teaching, 39(2), 85-101. doi: https:// doi.org/10.1515/iral.39.2.85

DfES (2004). Pedagogy and practice: Teaching and learning in secondary schools. Leadership guide. Retrieved from http://learning.gov.wales/docs/learningwales/publications/130423pedagogy-and-practice-teaching-and-learning-in-secondary-schools-en.pdf

Ebrahimi, Y., \& Hajmalek, E. (2016). The Impact of Error Correction Strategies of Speaking Tasks on the Anxiety Level of Intermediate EFL Learners. Journal of Applied Linguistics and Language Research, 3(6), 105-116.

Education First (2016). EF EPI English proficiency index. Retrieved from http://www.ef.com/ / / media/centralefcom/epi/downloads/full-reports/v6/ef-epi-2016-spanish-latam.pdf

Elliott, J, (1991). Action research for educational change. Philadelphia: McGraw-Hill.

Hargreaves, D. H. (2004). Personalising learning 2: Student voice and assessment for learning. London: Specialist Schools and Academies Trust.

Jefferson, G. (2004). Glossary of transcript symbols with an introduction. In G. H. Lerner (Ed.), Conversation Analysis: Studies from the First Generation (pp. 13-31). Amsterdam: John Benjamins. doi: https://doi.org/10.1075/pbns.125.02jef

MINEDUC. (2016). Estudio de caracterización, percepción y expectativas de la población que asiste a establecimientos educativos para personas jóvenes y adultas. Retrieved from http://epja. mineduc.cl/wp-content/uploads/sites/43/2016/11/Resumen-ejecutivo-EPJA.pdf 
doi: http://dx.doi.org/10.15359/ree.23-3.5

URL: http://www.una.ac.cr/educare

CORREO: educare@una.cr

Nazarova G.P, \& Umorova Kh. H, (2016). Self-confidence and its importance in learning languages. The International Scientific Journal, 4, 47-49.

OECD. (2006). Personalising education. Paris: Author. doi: https://doi.org/10.1787/9789264036604-en

OECD. (2009). Education at a Glance 2009 OECD Indicators. Paris: Author. doi: https://doi. org/10.1787/eag-2009-en

Ölmezer-Öztürk, E. (2016). Beliefs and practices of Turkish EFL teachers regarding oral corrective feedback: a small-scale classroom research study. The Language Learning Journal, 1-10. doi: https://doi.org/10.1080/09571736.2016.1263360

Pirhonen, N. (2016). Students' perceptions about the use of oral feedback in the EFL classrooms (Master thesis). University of Jyväskylä, Finland. Retrieved from https://jyx.jyu.fi/bitstream/ handle/123456789/49927/1/URN\%3ANBN\%3Afi\%3Ajyu-201605252709.pdf

Sadler, D. R. (1989). Formative assessment and the design of instructional systems. Instructional Science, 18, 119-44. doi: https://doi.org/10.1007/BF00117714

Sadler, D.R. (2010). Beyond feedback: Developing student capability in complex appraisal. Assessment \& Evaluation in Higher Education, 35(5), 535-550. doi: https://doi. org/10.1080/02602930903541015

Sandín, M. P. (2003). Investigación Cualitativa en educación: Fundamentos y tradiciones. Madrid: McGraw-Hill/Interamericana de España.

Steiner, P (2014). The Impact of the Self-Awareness Process on Learning and Leading, New England Journal of Higher Education. Retrieved from https://nebhe.org/journal/theimpact-of-the-self-awareness-process-on-learning-and-leading/

Tedick, D. J., \& De Gortari, B. (1998). Research on Error Correction and Implications for Classroom Teaching. ACIE Newsletter, 1(3). Retrieved from http://www.carla.umn.edu/immersion/ acie/vol1/May1998.pdf

Tolkhah, M. (2008). The effect of teacher's feedback in speaking class on students'learning experience (Thesis de Licenciatura). Sanata Dharma University, Indonesia. Retrieved from https:// repository.usd.ac.id/5883/2/031214108 Full.pdf

Willis, J. (1996). A framework for task- based learning. Harlow: Pearson.

Wolfe, S., \& Alexander, R. J. (2008). Argumentation and dialogic teaching: Alternative pedagogies for a changing world. London: Futurelab. Retrieved from https://issuu.com/gfbertini/docs/ future learning - argumentation and dialogic teach 